\title{
“Decoupling” effect as a factor of regional sustainable development (evidence from Volgograd Region)
}

\author{
Irina Anikina \\ Volgograd State University, \\ Institute of Economics and Finance \\ Corporate Finance and Banking Department \\ Volgograd, Russia \\ anikina@ volsu.ru
}

\author{
Albina Gukova \\ Volgograd State University, \\ Institute of Economics and Finance \\ Corporate Finance and Banking Department \\ Volgograd, Russia \\ gukova@volsu.ru
}

\author{
Andrey Anikin \\ Volgograd State University, \\ Institute of Economics and Finance \\ Corporate Finance and Banking Department \\ Volgograd, Russia \\ kfbd@volsu.ru
}

\begin{abstract}
Enhancing public well-being while reducing environmental problems and risks is a key aspect of sustainable development conception. To characterize sustainable development, indicators systems are developed that enable to adequately assess the means used and the level of goals achievability as well as effective monitoring and management of regional environmental and economic policies. To assess the impact of economic processes on the environment in global practices decoupling analysis which is based on calculating the decoupling index is applied. The traditional calculation of the decoupling index can hardly give a deep evaluation of the "decoupling" effect (i.e. reveal whether the effect is absolute or relative). The paper proposes a model for analyzing the ecological and economic state of a region on the basis of calculating the adjusted decoupling index, which helps to assess the absolute and relative decoupling effect. Using the proposed model the decoupling effect is analyzed in the Volgograd region in terms of pollutant emissions from stationary sources and discharges of contaminated wastewater. The results suggest the robustness of the proposed model and its advantages over the currently applied decoupling analysis algorithms, which will enable to more efficiently substantiate the measures to support projects in the field of green economy and achieve the goals of sustainable development at the regional level.
\end{abstract}

Keywords- "green" economy, sustainable growth, regional economy, ecological and economic effect, the "decoupling" effect

\section{INTRODUCTION}

The importance of addressing environmental problems both in individual regions and on the global scale, as a whole, is beyond any argument, since it is the quality of the environment that forms the quality of the people's life. Awareness of the environmental problems, their interrelation and interdependence with economic problems has resulted in building the conception of sustainable economic growth and developing the "green growth" theory. These conceptions and theories are being actively discussed and implemented in the practices of global and regional economies. They are the basis for making political, economic, financial and technical decisions both at intergovernmental level and at the level of certain nations, regions, companies and each person individually. The principles of the green economy were presented in the United Nations Environmental Programme (UNEP) Report “A Global Green New Deal” in 2009 [1]. It was the year of the global financial crisis, and it was the crisis that led to the awareness of impossibility of further development based on the model of pre-crisis economic growth. The Programme identified the critical directions and principles of investment in the post-crisis economy, such as: stimulating investment in non-waste technologies, regenerating the infrastructure of the environment (forests, water resources, air and soil). Sustainable economic growth should be ensured by recreating and developing the "green" infrastructure and improving the quality of peoples' life.

The pre-crisis years, according to the Report [1, p.4], were characterized by investments in "property, fossil fuels and structured financial products with embedded derivatives, but relatively little money was invested in renewable energy sources, energy saving, public transport, sustainable rural economy, as well as in the protection and rational use of land and water resources". It resulted in "multiple" crises $[1$, p. 5]: financial, negative climate change, food and fuel crises. This has led to the understanding and development of new goals for the global economy, such as: 1) preservation and creation of new jobs, protection of the poorest population strata (shortterm prospects); 2) achievement of "the Millennium 
Development Goals". The latter include elimination of poverty, reduction of carbon emissions, restoration of ecosystems and ensuring sustainable economic development. Thus, the concept of sustainable economic development links the improvement of people's well-being with the reduction of environmental risks and declares economic growth accompanied by simultaneous improving/not deteriorating the environment.

Promoting the development of the green economy requires elaborating an appropriate system of economic mechanisms and instruments, increased investment in environmental protection, and green technologies. The proceedings of the Third International Conference on Financing Development claim: "The global needs for investment in infrastructure water supply, agriculture, telecommunications, energy, transport, buildings, industry and forestry - account for between 5 to 7 trillion US dollars annually" [2, p. 5]. But in the context of limited and inefficient distribution of financial resources, it is necessary to prioritize investment and stimulation of environmental projects and programs as well as take into account the multiple effects of projects in terms of maximizing the interests of investors, consumers, and the region.

To analyze the environmental and economic state of the regions the decoupling index is applied in global practices [3]. It characterizes the "decoupling" effect, i.e. "splitting", "uncoupling" the growth rates of economic growth (GDP, GRP) and the growth rates of natural resources consumption and production and consumption. The presence of a decoupling effect is a necessary condition for the sustainable development of regions. Evaluation of the "decoupling" effect in the regional economy will enable to rank regions in terms of the level of their environmental and economic development, draw conclusions about the effectiveness of environmental and economic policies in the regions.

In the studies of Dumnov A.D., Boriskin D.A., Rybal'skii N.G. we can see a simplified approach to the conclusions drawn on the basis of traditional decoupling analysis. They also claim that "the recognition of decoupling indicators ... on the part of individual scientists and specialists in Russia has been seriously delayed" [4, p. 45].

The analysis of the "decoupling" effect in a number of Russian regions and industries was presented in the works of Akulov A.O. [5], Samarina V.P. [6], Shkiperova G.I. [7], Yakovleva E.Yu. [8], Yashalova N.N. [9]. It should be noted that consistent studies on the assessment of economic and environmental efficiency of the Volgograd region in the academic literature are not widely presented.

The purpose of the present study is to identify the relationship between the results of companies' economic activities and the change in the ecological state of the region by the example of the Volgograd region, and to develop a model of in-depth decoupling analysis. The proposed model and conclusions drawn can be applied to monitor the ecological and economic state of the region, as well as when developing and adjusting environmental and economic development programs for the regions.

\section{MATERIALS AND METHODS (MODEL)}

To analyze the effectiveness of the ecological and economic state of the regions, the calculation of the decoupling index is carried out. The decoupling index enables to assess the presence of the "decoupling" effect, specifically the extensity or intensity of economic development in relation to the use of natural resources and environmental conditions. There are the following types of decoupling [3]:

- relative decoupling - in which the resulting indicator (the indicator of economic growth) grows faster than the environmental one (resource costs or environmental pollution);

- absolute decoupling - characterizes the growth of the economic indicator with a decrease in the environmental one;

- zero decupling - characterizes the absence of significant discrepancies between the analyzed indicators.

The "decoupling" effect is calculated on the basis of the decoupling index (DI) for a certain period of time (usually a year) by the formula:

$$
\mathrm{DI}=\mathrm{T}_{\mathrm{R}} / \mathrm{T}_{\mathrm{Y}} \text {, }
$$

where: TR - relative change (growth factor) of the consumed resource or pollution release for a certain period;

Ty - relative change (growth factor) of the resulting indicator (typically GDP, GRP, etc.) for the same period;

DI - Decoupling index, expressed in relative units;

at DI $>1$ - the effect of "decoupling" is missing consumption of resources or environmental pollution occurs at a faster rate than economic growth, intensive pollution of the environment does;

at $\mathrm{DI}=1$ rates of economic growth and environmental pollution are identical;

at DI $<1$ there is a decoupling effect - the economic growth rate is higher than the rate of environmental pollution.

The decoupling index, calculated by the formula (1), makes it possible to assess the presence of the "decoupling" effect, but does not indicate whether this effect is absolute or relative. There is also no possibility to drive at deeper conclusions about the ecological and economic situation in the region. To overcome these shortcomings, the authors propose a model for analysis of the "decoupling" effect. The model (Fig. 1) is based on the comparison of the growth rates of consumed resources and / or pollution and indicators of economic growth. The adjusted decoupling index in the model is calculated by the following formula:

$$
\mathrm{DI}^{\prime}=\mathrm{T}_{\mathrm{R}}^{\prime}-\mathrm{T}_{\mathrm{Y}}{ }^{\prime} \text {, }
$$

where: DI' is the adjusted decoupling index, expressed in relative units,

$\mathrm{TR}^{\prime}$ - coefficient of increase in consumed resource or emission of pollution for a certain period, relative units, 
$\mathrm{TY}^{\prime}$ - the growth rate of the resultant indicator for the same period, relative units.

The model enables to identify six sectors that characterize the varying degree of effectiveness of the ecological and economic state in the region. In Fig. 1, the sectors are numbered from the best to the worst ones.

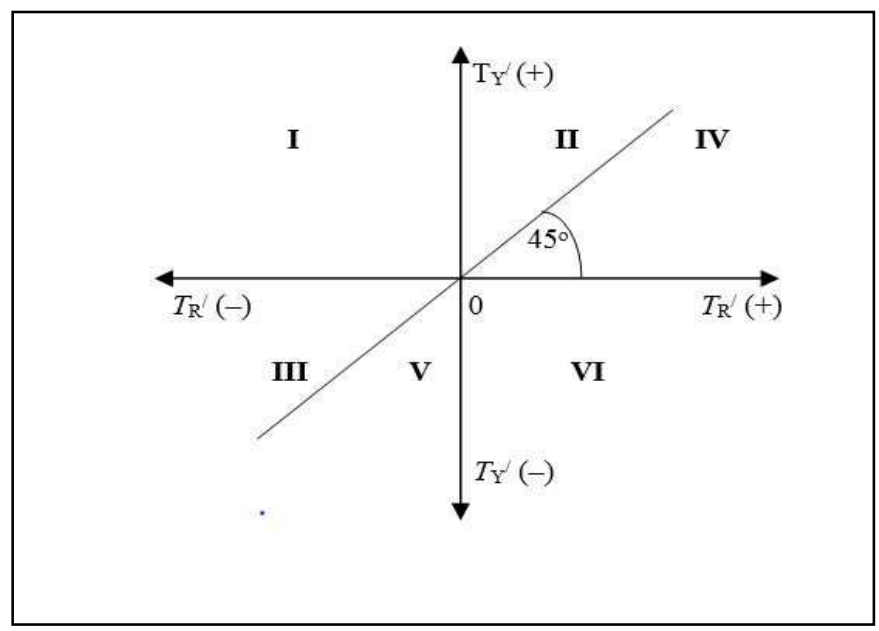

Fig. 1. The model of decoupling effect assessment. Source: the authors' model.

Sector $\mathrm{I} \mathrm{TR}^{\prime}(-)>\mathrm{TY}^{\prime}(+), \mathrm{DI}^{\prime}<0-$ the presence of the "absolute decoupling" effect. The most favorable situation for the region's economy is characterized by a decrease in the environmental load in the region with simultaneous economic growth, sustainable development of the region.

Sector II: $\mathrm{TR}^{\prime}(+)<\mathrm{TY}^{\prime}(+), \mathrm{DI}^{\prime}<0$ - the presence of the "relative decoupling" effect. The normal situation, the growth in the efficiency of the region's economy is accompanied by an increase in environmental costs. The negative impact on the environment is increasing, but the decoupling index remains negative, which indicates the sustainable development of the region.

Sector III: $\mathrm{TR}^{\prime}(-)>\mathrm{TY}^{\prime}(-), \mathrm{DI}^{\prime}<0-$ the presence of the "relative decoupling" effect. The situation is characterized by a decrease in the environmental burden on the region with a simultaneous decrease in GRP, but the environmental burden decreases faster than economic results. Such a situation is possible in conditions of restructuring production, transition to new innovative technologies.

Sector IV: $\mathrm{TR}^{\prime}(+)>\mathrm{TY}^{\prime}(+), \mathrm{DI}^{\prime}>0-$ no decoupling effect is found. It suggests slowing down the effectiveness of the region's ecological and economic development. There is an accelerated load on the ecological condition of the region, but economic growth is also observed. One should put an emphasis on the support of "green" technologies and projects.

Sector $\mathrm{V}$ : $\mathrm{TR}^{\prime}(-)<\mathrm{TY}^{\prime}(-), \mathrm{DI}^{\prime}>0$. The decoupling effect is absent. For this situation, a decrease in the environmental load is typical, while the regional economy performance indicators are simultaneously deteriorating.

Sector VI: TR / (+)> TY / (-), DI /> 0 - no decoupling effect is present. It suggests the worst, crisis situation, in which the growing burden on the ecology of the region is accompanied by a worsening economic situation.

The proposed model has enabled to identify sectors that demonstrate the qualitatively different degree of effectiveness in terms of the region's environmental and economic policy implementation. It will facilitate diagnosing the environmental and economic problems of the region in a timely manner and contribute to taking appropriate decisions on measures to support environmental projects and programs as well as their expediency, adjustment and restructuring.

\section{RESULTS AND DISCUSSION}

Environmental safety issues in Russia are among the priorities of its national policy: a significant number of regulatory documents and programs aimed at stimulating green investments and innovations, preserving and restoring the environment have been adopted. The year 2017 was declared the Year of Ecology in Russia to "attract the public attention to the issues of the ecological development of the Russian Federation, preserving biological diversity and ensuring environmental safety" [10]. As it is noted by the Ministry for Natural Resources and Ecology of the Russian Federation, "the key decisions of the year are the implementation of the best available environmental technologies, improvement of environmental indicators of the regions, enhancement of the waste management system, protection of the Baikal natural territory, preservation of water, forest and land resources, development of the protected system" [11].

The Volgograd Region actively participated in this project: a two-year program was developed to minimize the negative impact on the environment. About 25 billion rubles are to be allocated for achieving the program's purposes. Summing up the Year of Ecology in the region, the Committee of Natural Resources, Forestry and Ecology of the Volgograd Region presented the following results aimed at reducing the harmful impact on the environment [12]:

- $\quad$ in the field of ecological modernization of industrial enterprises: commissioning of a water treatment plant for circulating cycles at JSC "Volzhsky Pipe Plant"; reconstruction and commissioning of the hydrotreating unit, the installation of furnaces with a combustion management system at LukoilVolgogradnefteperabotka Ltd; launch of a cement clinker production line using the technology of "dry" energy-saving technology at Serebryakovcement JSC;

- in the field of atmospheric air monitoring: the implementation of 30 investment projects by industrial enterprises with the introduction of modern technologies with high environmental characteristics for a total of about 30 billion rubles;

- in the sphere of the multichannel water industry modernization in Volgograd: investing 30 billion rubles is scheduled for the coming 30 years;

- $\quad$ in the field of waste management: a territorial cluster scheme for waste management has been developed; a 
new polygon in the Svetloyar district built; three garbage sorting lines and two processing complexes are being constructed; in the framework of the Clean Country project, the landfill in the Kirovsky district of Volgograd is being eradicated, and projects for the liquidation of 21 landfills in Sredneakhtubinsky, Uryupinsky, Kamyshinsky and Dubovsky districts have been developed.

The implementation of this and other projects in the field of ecology should reduce the burden on the environment of the region, increase the investment attractiveness of the Volgograd region, and improve the quality of citizens' life. For a more comprehensive analysis of the relations between environmental and economic processes in the region, we will carry out calculations in the framework of decoupling analysis (formula 1). Russian scientists who conducted the decoupling analysis for various Russian regions [5, 6, 7, 8, 9], having demonstrated a general methodological unanimity in treating the essence of the "decoupling" effect, in practice seem to apply different calculation indices. Thus, the researchers used the following indicators in their analyses: economic - gross regional product, volume of industrial production, growth of the population well-being; indicators of anthropogenic impact on the environment are treated as indicators of environmental pollution. Moreover, the resource saving assessment is carried out by analyzing specific sectoral indicators, for example, for mining industries: ore extraction volumes, the area of tilled land, the area of lands with disturbed water balance, etc., along with environmental and economic accounting indicators.

For the decoupling analysis in the Volgograd region, the following indicators have been used: emissions of pollutants from stationary sources, discharge of contaminated sewage into surface water bodies, GRP at comparable prices in relation to the previous year. The choice of parameters is due to the fact that they are statistically observable over a long period (data are used for 10 periods) and can be applied for comparative analysis by region.

The conducted studies for individual Russian regions (data used for 2000-2012) have showed the following results:

A) the presence of the "decoupling" effect in the Murmansk region [6] (in terms of the relationship between the emission of pollutants into the atmosphere from stationary sources and the dynamics of GRP), in the Belgorod region (reduced emissions of pollutants from stationary sources and improvement of the chemical composition of surface waters), in the Krasnodar region (the relationship between industrial production and atmospheric emissions);

B) the negative decoupling effect in the Rostov region [6] (increase in the environmental pollution following a reduction in the intensity of industrial production), in the Kemerovo region by the coal industry [5], in the Republic of Karelia [7] (positive - in relation to pollutant emissions substances from stationary sources, and negative - in terms of long-term forecast);

C) the positive decoupling effect in the Vologda region for the metallurgical industry and a minor effect for the chemical industry [9].

E. Yakovleva's study [8] has estimated the flow of natural resources and pollution for the regions and sectors of the Russian economy. The decoupling effect is calculated on the basis of water use indicators, wastewater discharge, air pollution from mobile and stationary sources in general, as well as separately for carbon monoxide, sulfur dioxide, nitrogen oxides, hydrocarbons, volatile organic compounds, solid particles in the federal districts of Russia. She has showed that "for all of these resources and pollution in Russia and individual federal districts, there is either an absolute or a relative decoupling effect" [8]. The presented dynamic assessment of the region's ecological and economic "success" in 80 Russian regions has enabled to rank regions in terms of the level of their economic impact on the environment. The Volgograd region has been classified as a medium-developed agro-industrial region, and the level of its ecological and economic "success" has steadily increasing at an insignificant rate (from 0.531 in 2007 to 0.604 in 2013 , with the maximum possible level of 1.00). We consider it necessary to assess the environmental and economic situation in the Volgograd region, develop proposals for improving the environmental status of the region, substantiate the volumes and sources of funding for environmental activities and projects, and carry out the decoupling analysis. It has been applied to calculate the decoupling index for the Volgograd Region (Table 1, Figures 2.3) both using the traditional approach (by formula 1) and the model proposed by the authors (formula 2, Fig. 1). 
TABLE 1. Calculation of the decoupling effect for Volgograd region

\begin{tabular}{|c|c|c|c|c|c|c|c|c|c|c|c|}
\hline Indiators & 2005 & 2006 & 2007 & 2008 & 2009 & 2010 & 2011 & 2012 & 2013 & 2014 & 2015 \\
\hline $\begin{array}{l}\qquad \mathrm{R}_{1} \\
\text { thousand tons }\end{array}$ & 221.4 & 221.3 & 226.9 & 221.4 & 194.9 & 201.1 & 178.2 & 170.9 & 172.8 & 153.5 & 160.0 \\
\hline $\begin{array}{c}\mathrm{R}_{2} \\
\text { million cubic } \\
\text { meters }\end{array}$ & 204.0 & 217.0 & 203.07 & 218.27 & 200.22 & 186.34 & 149.50 & 144.4 & 141.2 & 122.62 & 104.21 \\
\hline $\begin{array}{l}\mathrm{T}_{\mathrm{Y}} . \\
\text { rel. un. }\end{array}$ & 1.050 & 1.020 & 1.070 & 1.057 & 0.870 & 1.037 & 1.033 & 1.028 & 1.014 & 1.047 & 0.938 \\
\hline $\begin{array}{l}T_{R 1} \\
\text { rel. un. }\end{array}$ & 0.000 & 1.000 & 1.025 & 0.976 & 0.880 & 1.032 & 0.886 & 0.959 & 1.011 & 0.888 & 1.042 \\
\hline $\begin{array}{l}\mathrm{T}_{\mathrm{R} 2} \\
\text { rel. un. }\end{array}$ & 0.000 & 1.064 & 0.936 & 1.075 & 0.917 & 0.931 & 0.802 & 0.966 & 0.978 & 0.868 & 0.850 \\
\hline $\begin{array}{c}\mathrm{T}_{\mathrm{Y}}^{\prime} \\
\text { rel. un. }\end{array}$ & 0.000 & 0.020 & 0.070 & 0.057 & -0.130 & 0.037 & 0.033 & 0.028 & 0.014 & 0.047 & -0.062 \\
\hline $\begin{array}{l}\mathrm{T}_{\mathrm{R} 1}^{\prime} \\
\text { rel. un. }\end{array}$ & 0.000 & 0.000 & 0.025 & -0.024 & -0.120 & 0.032 & -0.114 & -0.041 & 0.011 & -0.112 & 0.042 \\
\hline $\begin{array}{c}\mathrm{T}_{\mathrm{R} 2}{ }^{\prime} \\
\text { rel. un.. }\end{array}$ & 0.000 & 0.064 & -0.064 & 0.075 & -0.083 & -0.069 & -0.198 & -0.034 & -0.022 & -0.132 & -0.150 \\
\hline $\mathrm{DI}_{1}$ & 0.000 & 0.980 & 0.958 & 0.923 & 1.012 & 0.995 & 0.858 & 0.933 & 0.997 & 0.848 & 1.111 \\
\hline $\mathrm{DI}_{2}$ & 0.000 & 1.043 & 0.875 & 1.017 & 1.054 & 0.897 & 0.777 & 0.940 & 0.964 & 0.829 & 0.906 \\
\hline $\mathrm{DI}_{1}^{\prime}$ & 0.000 & -0.020 & -0.045 & -0.081 & 0.010 & -0.005 & -0.147 & -0.069 & -0.003 & -0.159 & 0.104 \\
\hline $\mathrm{DI}_{2}^{\prime}$ & 0.000 & 0.044 & -0.134 & 0.018 & 0.047 & -0.106 & -0.231 & -0.062 & -0.036 & -0.179 & -0.088 \\
\hline $\begin{array}{l}\text { Sector } \\
\left(\text { by } \mathrm{R}_{1}\right)\end{array}$ & 0 & II & II & I & $\mathbf{V}$ & II & I & I & II & I & VI \\
\hline $\begin{array}{l}\text { Sector } \\
\left(\text { by } R_{2}\right)\end{array}$ & 0 & IV & I & IV & $\mathbf{V}$ & I & I & I & I & I & III \\
\hline
\end{tabular}

Note: TY - index of the physical volume of GRP (GRP in comparable prices in relation to the previous year); $\mathrm{R}_{1}$ - emissions of pollutants from stationary sources; $\mathrm{R}_{2}$ - discharge of contaminated sewage into surface water bodies; $\mathrm{DI}_{1}, \mathrm{DI}_{2},-$ decoupling indices; $\mathrm{DI}_{1}^{\prime}, \mathrm{DI}_{2}^{\prime}$ - adjusted decoupling indices.

Source: Authors' calculations based on data [13].

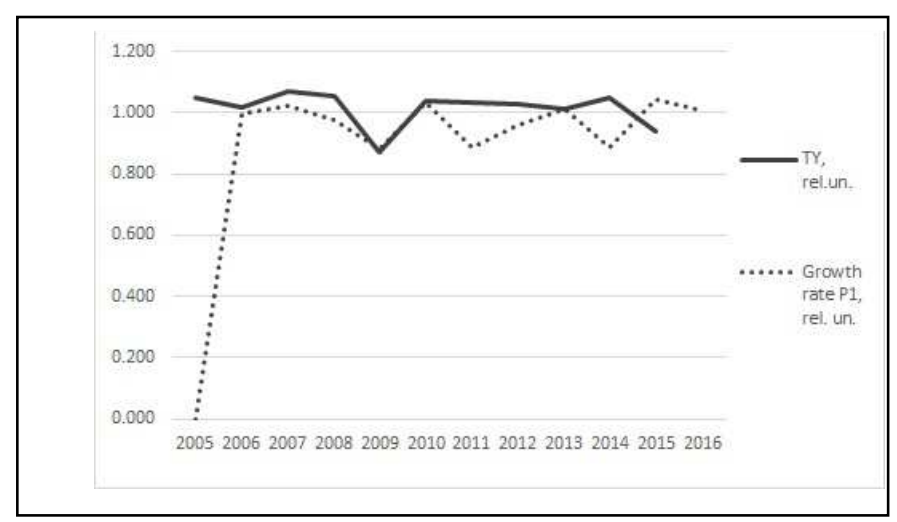

Fig 2. Decoupling effect for the Volgograd region (emissions of pollutants from stationary sources). Source: the authors' calculations.

\section{CONCLUSION}

A) The Decoupling analysis of the ecological and economic state of the region, conducted for the Volgograd region for the period between 2006 and 2015 has showed an

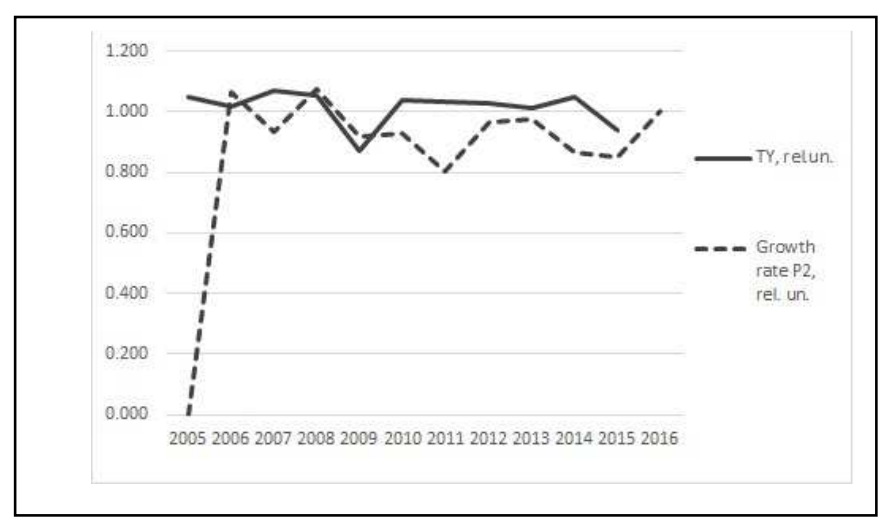

Fig 3. Decoupling effect for the Volgograd region (on discharges of contaminated sewage into surface water bodies). Source: the authors' calculations.

unstable "decoupling" effect by "emissions of pollutants from stationary sources" and "discharge of contaminated sewage into surface water bodies" indicators. In four out of ten analyzed periods, the "decoupling" effect was absent (in 2006, 
2008, 2009, 2015), which characterizes the ecological situation in the region as relatively unstable.

B) The Analysis of the adjusted decoupling index, according to the model proposed by the authors, has demonstrated the following results: the presence or absence of the decoupling effect does not contradict the results obtained by the algorithm of traditional decoupling analysis. However, approbation of the proposed model has made it possible to draw the following conclusions: the "decoupling" effect in those periods when it was present, is characterized primarily as "absolute". So, in terms of "emissions of pollutants from stationary sources" in four of the seven periods of having a decoupling effect $(57 \%)$, it was absolute. In terms of "discharge of contaminated sewage into surface water bodies", the "decoupling" effect was present in seven periods, in six of them it was absolute (86\%). Thus, the ecological and economic state of the region can be assessed as having a positive dynamic.

C) The proposed model of analysis of the "decoupling" effect is useful for assessing the ecological and economic status of regions and mechanisms for supporting "green" projects as well as for monitoring the implementation of innovative eco-saving technologies. The assessment of both the presence and absence of the "decoupling" effect, and its deeper analysis, will enable to draw some conclusions concerning the investment attractiveness of the region for the implementation of innovative projects in the field of "green" technologies, the selection of optimal sources of funding and their parameters.

\section{References}

[1] A Global Green New Deal. Report, March 2009. Published by the United Nations Environment Program under the Green Economy Initiative. http://www.unepcom.ru/images/greeneconomy/greennewdeal.pdf.

[2] Proceedings of the Third International Conference on Financial Development. http://www.un.org/sustainabledevelopment/wpcontent/uploads/2015/07/FFD-Press-Kit-Russian-ONLINE.pdf

[3] System of Environment-Ecomonic Accounting 2012 : Applications and Extensions (White cover publication/ pre-edited text subject to official editing). Eurorean Commission, FAO, OECD, United Natoins, World Bank, 2014b.
[4] Dumnov, A.D., Boriskin D.A., Rybalsky N.G., " On some methods of macrostatistical analysis of nature management and protection of the environment" [O nekotorykh metodakh makrostatisticheskogo analiza prirodopol'zovaniya i okhrany okruzhuyushchei sredy], in The age of globalization [Vek globalizatsii], Vol. 2, 2017, pp. .37-50.

[5] Akulov A.O., "Decoupling effect in the industrial region (by the example of the Kemerovo region)" [Effekt dekaplinga $\mathrm{v}$ industrial'nom regione (na primere Kemerovskoi oblasti)], in Economic and social changes: facts, trends, forecast [Ekonomicheskie i sotsial'nye peremeny: fakty, tendentsii, prognoz], Vol 4 (28), 2013, pp. 177-185.

[6] Samarina V.P., "Green" economy of Russia: some questions of theory and methodology" [«Zelenaya» ekonomika Rossii: nekotorye voprosy teorii i metodologii], in National interests: priorities and security [Natsional'nye interesy: prioritety i bezopasnost'], Vol. 2 (287), 2015, pp. 2-9.

[7] Shkiperova G.I., "Analysis of modeling the relationship between economic growth and environmental quality (by the example of the Republic of Karelia)" [Analiz modelirovaniya vzaimosvyazi mezhdu ekonomicheskim rostom i kachestvom okruzhayushchei sredy (na primere Respublike Kareliya)], in Economic analysis: theory and practice [Ekonomicheskii analiz: teoriya i praktika], Vol. 43 (394), 2014, pp. 41-49.

[8] Yakovleva E.Yu., "Economic evaluation of interbranch flows of natural resources and pollution", diss. ... Cand. Econ. Sciences: 08.00.05. - M., 2016, 169 p.

[9] Yashalova N.N., "Analysis of the manifestation of the decoupling effect in the ecological and economic activity of the region" [Analiz proyavleniya effekta dekaplinga v ekologo-ekonomicheskoi deyatel'nosti regiona], in Regional economy: theory and practice [Regional'naya ekonomika: teoriya i praktika], Vol. 39 (366), 2014, pp. 54-60.

[10] Decree of the President of the Russian Federation of 05.01.2016 \# 7 "On the Year of Ecology in the Russian Federation". http://kremlin.ru/events/president/news/51142

[11] 2017 - Year of Ecology in Russia // http://ecoyear.ru/about/

[12] the Committee for Natural Resources, Forestry and Ecology of Volgograd Region. Official Website. // http://oblkompriroda.volgograd.ru/

[13] The Territorial Body of State Statistics for the Volgograd Region Official website.

http://volgastat.gks.ru/wps/wcm/connect/rosstat_ts/volgastat/ru/statistics /environment/,

http://volgastat.gks.ru/wps/wcm/connect/rosstat ts/volgastat/ru/statistics lgrp/ 